\title{
The world of spirits and the respect for nature: towards a new appreciation of animism
}

HEINZ KIMMERLE*

\begin{abstract}
The belief in spirits has diminished in Western thought since Enlightenment. But it has not disappeared totally. In the subconscious of people and in different subcultures and also in literature and art it is still alive. Derrida, before his death, worked out a new spectrology in which the status of reality of spirits is interpreted as absently present.

In Sub-Saharan African thought this belief is broadly present and deeply rooted. It is the core of traditional African religions. Also intellectuals, although they may have taken over Christian or Islamic convictions, mostly stick to this belief.

An important aspect of the African belief in spirits is that they also dwell in nature. In principle they can choose for all natural things to dwell in them, and there is a special inclination for trees. The spiritual conception of reality as a whole is called animism. This important religion has been devaluated in connection with colonialism. Recently the respect for nature which comes forth from this religion is highly appreciated by ecological philosophy.
\end{abstract}

Keywords: Sprits, spectrology, Derrida, Marx, Enlightenment, nature, animism, Africa, Christianity, Islam, religion, ecological philosophy.

\section{Introduction}

The belief in spirits is widespread and deeply rooted in sub-Saharan Africa. It forms the essential core of African religions. Belief is not meant here in the sense of not knowing. The vast majority of African people are convinced of the reality of the world of spirits. That is also true for most of the academically trained and of those who have

* Heinz Kimmerle, born in 1930, is emeritus professor in Philosophy at the Erasmus University in Rotterdam, in the Netherlands. The last five years before his retirement in 1995 he occupied a special chair for the Foundations of Intercultural Philosophy. His particular interest is the dialogue between Western and African Philosophy. In 2004 he received an honorary doctorate from the University of South Africa (UNISA), and in 1997, 1998, 2002 and 2006 he taught as guest professor at the University of Venda in Thohoyandou, South Africa. 
become Christians or Muslims. In a first paragraph I will describe more in detail what the belief in spirits means in African thought and feeling.

In a second paragraph the judgment of African philosophers on this belief is brought to the fore. Leading philosophers point out that they do not see any opposition between spirituality and rationality. They even state that the development of epistemology in modern sciences is more in line with African ideas about spirits and about reincarnation than Western conceptions, which stick to the traditional Kantian model.

But also in the thought and feeling of Western people the belief in spirits has not disappeared totally since Enlightenment. It rather seems to me that with us Western people the organ has become stunted by which the reality of spirits can be perceived. In the subconscious and in subcultures, and also in literature and art in general, and in ordinary language, spirits still play an important role also in Western culture. In the third paragraph I will give an explanation of the mode of 'absent presence' of spirits in Western thought and feeling. In doing this, I will follow Derrida's work to establish a new theory of spirits (spectrology).

An important aspect of the African belief in spirits is the assumption that spirits can also dwell in nature, in principle in all natural things. Especially favoured dwelling-places are trees, and among the trees, before all, the mighty Baobabs which are regarded as being holy. But also certain special places, lakes and woods or pieces of land close to a waterfall are preferred dwelling-places of spirits in nature. In the fourth paragraph I will refer to the project of Wangari Maathai, the mother of the trees, who has got the Nobel Peace Prize for her work of planting millions of trees in Kenya and East Africa, together with the Green Belt Movement which she had founded in the 1970s.

The belief that spirits dwell in nature, that - in other words - all things in nature have or can have a soul is the basic idea of animism. This important religion has been devalued in connection with the low esteem for indigenous cultures by colonialism and Christian missionary activities. In recent times the meaning of this religion for an ecologically conscious way of thinking and acting, for the protection and sustaining of nature, has become obvious. In the fifth paragraph I will plead that we need to come to a new appreciation of animism as one the so-called great world-religions like Judaism, Christianity, Islam, Hinduism and Buddhism.

In conclusion, I will quote three African proverbs on trees, one of the Ashanti in Ghana, one of the Kikuyu in Kenya and one which is common in many African communities. They will show that the respect for nature goes together with quite sober and pragmatic opinions in African thought. 


\section{The world of spirits in African thought and feeling}

According to the belief of African people south of the Sahara, in the reality of the universe as a whole and also in the human world, spirits are present and play an important role. ${ }^{1}$ This is an expression of the over-all effective spirituality of African thought and feeling. In this respect, Ellis and Ter Haar are a bit reserved in their judgment. In Worlds of Power they state:

The spirit world (as the core idea of African religion still) is commonly considered the ultimate source of power, (although) recent research suggests that more Africans are indifferent to religion than in the past. ${ }^{2}$

With regard to the presence of the spirits there is one fundamental difference: their presence in the visible and in the invisible world. In the visible world the spirits are connected to the physical part of human existence and the things in the world. In the invisible world they are present without this connection, purely as spirits. They probably possess a non-physical bodily existence. They can be present at different places at the same moment and they can overcome huge distances of space in no time.

The visible and the invisible world, however, are not divided from each other. They form one and the same scene. Therefore, it would be apt to speak of the visible and invisible dimensions of the world. The now living people form together with animals and plants, the in-organic materials and the artefacts, the visible dimension of the world. The ancestors, those who have recently passed away, also called the 'living-dead', and those who died some time ago, but are still remembered by the now living, dwell as spirits in the invisible dimension of the world. And also the yet to be born are already present in this dimension.

The boundary between the visible and the invisible world cannot be drawn clearly. In dreams, in certain rituals, but also at unexpected occasions the spirits of the ancestors can appear and give messages or warnings to the now living people. The living-dead take care that the relations with the living which were not in order at the moment of passing away - because for instance a debt that had not been settled - are set right later.

In general the spirits of the ancestors can claim the privilege of being honoured, because they have founded and maintained the community of the now living. They are in charge of the further maintenance

1 For the text of this paragraph I am using primarily G Parrinder, African Traditional Religion, (Sheldon Press, London, 1961)3 as well as T Fourche and H Morlichem, Une bible noire, (Max Arnold, Brussels, 1973).

2 S Ellis and G ter Haar, Worlds of Power: Religious Thought and Political Practice in Africa, (Hurst \& Company, London, 2004), p. 6.

TD, 2(2), December 2006, pp. 249-263. 
of this community and give it necessary advice or orders.

The now living people become potential ancestors or get the qualification to become ancestors, when they pass away, during their lifetime. This happens before all by the initiation rites when they are informed about the basic knowledge of their culture and when they are circumcised. A chief, a member of the council of elderly people or the oldest sister of the head of the family act already during their life in the visible world as spirits, when they perform the tasks of the spirits for the community. Thus passing away or changing the mode of being from living in the visible dimension of the world to the existence in its invisible dimension is not necessarily a sudden experience or a radical break.

That the yet to be born are already present as spirits in the invisible dimension of the world, shows the spiritual character of the community as a whole. ${ }^{3}$ Those now living are part of an infinite stream of life which is traversing them. It is important to notice that the ancestors live and have influence on the community as long as they are remembered and that the yet to be born begin to exist as spirits when they are expected by the now living people. One area of influence of Christian ideas on African beliefs is to be found in the exposition that the spirits of the ancestors continue their living at some heavenly place when nobody remembers them any more. ${ }^{4}$

Although the spirits are more powerful as spirits in the invisible world, they long for coming back by reincarnation into the visible world. The visible world is said to be warmer and only here can the spirits participate in the fullness of life. That is also one of the reasons why African women wish to have many children. Thus they can offer more opportunities for the spirits to come back as babies to the visible world. In this connection it is possible, although it defies the conventional sense of logic, for a spirit to simultaneously partly come back into the visible dimension and partly remain in the invisible dimension of the world. ${ }^{5}$

It says much for the sense of reality in African thought that good and also evil spirits are assumed to co-exist. The fact that in the universe as a whole, and in the human world in particular, harmonic relations

3 JM Nyasani, "The Ontological Significance of 'I' and 'We' in African Philosophy" in H Kimmerle (ed), I, We and Body, (Grüner, Amsterdam, 1989), pp. 13-25.

4 MB Ramose, African Philosophy Through Ubuntu, (Mond Books, Harare, 1999), pp. 7078; For the influence of Christian ideas on African beliefs about afterlife Ramose refers mainly to the book of John S. Mbiti, African Religions and Philosophy, (Anchor, New York 1970).

5 SB Oluwole, Reincarnation: An issue in African philosophy, in her book: Witchcraft, Reicarnation and the God-Head, (Excel Publishers, Lagos, 1992), pp. 39-54. 
are pre-supposed, shows the stronger influences of the good over the bad spirits. This harmony is, however, endangered and has to be reinstalled and protected all the time. It can be thought of better as a dynamic equilibrium, which has to be maintained also by the living people and by the spirits acting in and through them. Therefore, it is very important that the living people develop a character in which good intentions and actions prevail. ${ }^{6}$ Taking into account what happened in Africa during the last decade (the mutual genocide of Hutu and Tutsi in Rwanda, the fighting between Hema and Lendu for participation in the exploitation of Koltan in the soil of their living area, or the civil war between Muslims and Christians in Sudan) one can have serious reservations about the ongoing cosmic harmony in the human world.

While the spirits of the ancestors and of the not yet born exist close to the living people, as it where on the same scene, the Supreme Being, who has many different names in the African languages, which are translated in the terminology of Christianity and other religions as God, is far away, at some place in heaven, from where he reigns the universe. In some parts of sub-Saharan Africa, especially in West Africa, we find besides the belief in spirits and in the Supreme Being the assumption of deities, who are situated between the spirits and the Supreme Being. They take care of the fertility of the land and of the women, of good weather, superiority in wars, often also of certain regions or places and the people living there or of one single person for whom they feel responsible. The Yoruba for instance, who live in the present states of Nigeria, Niger and Benin believe in hundreds of deities. ${ }^{7}$

\section{The judgment of African philosophers}

African philosophers have no problems with the religious beliefs of their peoples. Spirituality and rationality are not in opposition for them. They even confirm the rational status of the belief in spirits. This is documented by statements of Odera Oruka from the University of Nairobi when he was asked to give his opinion as an expert on a juridical case in court. The question under examination was whether or not a person who had passed away in Nairobi should be buried according to his own will in the environment of his friends and colleagues in this city, or in the village of his birth at a great distance from this place. Oruka advised that one should follow the traditional custom and bury this person in the village of his birth. The judge

6 K Gyekye, An essay in African philosophical thought: The Akan conceptual scheme, (Cambridge University Press, Cambridge, 1987), pp. 85-101 and 131-135.

7 C Staewen, Ifa - African Gods Speak: The Oracle of the Yoruba in Nigeria, (Springer Hamburg, 1996).

TD, 2(2), December 2006, pp. 249-263. 
feared that the spirits of the deceased would haunt those who take a decision against his will. Oruka responded to that by saying that a spirit can only haunt somebody 'if the customs are on its side'. Furthermore it must have a reason which is accepted in the world of spirits. Then the judge asked him:

As a Professor in our national university, do you believe that there are spirits?

And then he got the following answer:

I am still looking for reason why I should not believe in spirits. Perhaps it would be a service to scholarship and law if you could provide me with a reason. ${ }^{8}$

Appiah who had been teaching philosophy at the University of Ghana, was later appointed at Harvard University in the USA and is currently teaching at Princeton University in New Jersey, writes in an article on 'Old Gods, New Worlds':

Most Africans, now, whether converted to Islam or Christianity or not, still share the beliefs of their ancestors in an ontology of invisible beings ... These beliefs in invisible agents mean that most Africans cannot fully accept those scientific theories in the West that are inconsistent with it.

And he concludes:

We cannot avoid the issue whether it is possible to adopt adversarial, individualistic cognitive styles, and keep, as we might want to, accommodative communitarian morals. Cultures and people have often been capable of maintaining such double standards (and I use the term non-pejoratively, for perhaps we need different standards for different purposes).$^{9}$

Oluwole from the University of Lagos confronts the African option for a belief in spirits and in reincarnation with the Western epistemological conception to accept no explanation as reliable, which is not underpinned by sense data. She argues that after Kant the conditions for the possibility of reliable knowledge have changed, and especially in advanced sciences like quantum-mechanics. Therefore the African belief in phenomena which cannot be perceived by the senses is more likely to be true than Western epistemology which still follows the Kantian model. African experience gives according to her 'overwhelming empirical evidence' in support of the existence of spirits and of reincarnation. She summarises:

Today science has room for the possibility of reincarnation, although Logical Positivism does not. ${ }^{10}$

8 HO Oruka, Sage Philosophy. Indigenous Thinkers and Modern Debate on African Philosophy, (Brill, Leiden a.o., 1990), pp. 74-75.

9 KA Appiah, In My Father's House. Africa in the Philosophy of Culture, (Methuen, London, 1992), pp. 218-220.

10 SB Oluwole, Reincarnation: An issue in African philosophy, in her book: Witchcraft, Reicarnation and the God-Head, pp. 51-52. 
Gyekye, also from the University of Ghana, is critical with regard to the belief in the spirits. However, he does not doubt this belief itself; he fears that an 'excessive and incessant attention' to what the ancestors have done and would do, hampers the 'cultivation of an innovative spirit or outlook', which are necessary to make progress on the way to modernity. In a final analysis he tries to adapt the traditional 'values and attitudes' to the needs of the 'constellation of the presence'. In the fight against corruption he pleads for a reconnection with traditional values under changed circumstances. ${ }^{11}$

\section{The 'absent presence' of spirits in Western thought and feeling}

In advanced sciences in the West and elsewhere, the borderline between matter and energy is indeed no longer a strict one. And in the virtual reality of the computer we cannot only communicate directly worldwide; it is easy to create pictures with people moving through walls. There are many films on television and in the cinemas showing persons who disappear and re-appear in a mysterious way. Such phenomena can be understood as a new opening of the mind also in the Western world for the reality of spirits. After Enlightenment, in the West, the belief in spirits had never vanished completely. In certain subcultures, practices continued by which contact with the spirits of deceased persons is made. And examples for reincarnation, which have been collected, are manifold.

Jacques Derrida has worked out a new theory of the spirits, which he calls spectrology. In this theory he examines the 'absently present' or 'presently absent' dimension of reality. This work has been inspired by the ghostly presence in the thinking of Karl Marx and of the theory and practice of Marxism ('which might be a different thing') in the consciousness of the Western world after the fall of the Berlin Wall and the collapse of the power of the Soviet Union in Eastern Europe in 1989. ${ }^{12}$

Obviously, also Marx himself uses the argument of the presence of ghosts and spirits in his time. The first sentence of the Communist Manifesto, which he had written together with Engels in 1848, reads: 'A ghost haunts Europe, the ghost of communism'. ${ }^{13}$ By that, the

$11 \mathrm{~K}$ Gyekye, Tradition and Modernity. Philosophical Reflections on the African Experience, (Oxford University Press, New York/Oxford, 1997), pp. 257-258 and 203-215.

12 J Derrida, Spectres de Marx. L'Etat de la dette, le travail du deuil et la Nouvelle Internationale, (Galilée, Paris, 1993), p. 90. (I quote from the French edition. And I give my own translation.)

13 K Marx and F Engels, Manifest der Kommunistischen Partei (1848), in: Ausgewählte Schriften in zwei Bänden, (Dietz, Berlin, 1961), Vol. I, p. 15.

TD, 2(2), December 2006, pp. 249-263. 
authors do not refer to the ghosts in a positive way; they want the ghost to be real in the visible world, to become 'manifest'. ${ }^{14}$ In the German Ideology (1844/45) these authors deny Max Stirner's criticism of Hegel's philosophy, especially his Phenomenology of Spirit (1807). He calls Hegel's central notion of spirit a 'phantom'. The counterposition of Stirner, his solipsism, which recognises only the 'I' as the foundation of all reality, is looked at by Marx and Engels as a 'phantom of phantoms'. ${ }^{15}$ (212-119) They intend to make the spirits, ghosts and phantoms real by founding human life and human history on concrete labour. In this sense also the 'fetish-character of commodity' and the 'enchantment of money', with which Marx is dealing in volume I of The Capital, ${ }^{16}$ have to be abolished by a revolutionary change of capitalism and taking over the administration of any kind of work by the workers. ${ }^{17}$ The apparently ambivalent attitude of Marx towards ghosts, spirits and phantoms is summarised by Derrida in the sentence: 'Marx does not love the spirits who love him. ${ }^{18}$

Finally, Derrida comes to the conclusion: Whenever the interest in spirits comes up, this is a sign of a deep crisis in the thinking and acting of a time. He finds the key-scene for that in the beginning of Shakespeare's tragedy Hamlet. The ghost of his father appears to Hamlet and asks from him to take revenge for the injustice of having been murdered by his own wife and her lover. Hamlet expresses the difficulty of this task by saying: 'Time is out of joint:- O cursed spite That ever I was born to set it right.' Taking revenge for an injustice and setting right time, which is out of joint, obviously belong together. So there is a connection between the appearance of the ghost of Hamlet's father and the quest for right and justice. The ghosts and spirits not only ask for revenge, they also haunt those who commit injustice and cause the time to be out of joint. Therefore Derrida calls his new theory of spirits not only 'spectrology', but also 'hauntology'. ${ }^{19}$

Derrida does not want to turn around the 'collective exorcism' of European Enlightenment by assuring us that spirits do exist in reality. He leaves the case undecided. And he is content that the existence of spirits can no longer simply be denied. He states the presence of spirits in the mode of their absence. This is documented in ordinary language in which the 'spirit of a time' or of the 'obsession' of a person is

14 J Derrida, Spectres de Marx. L'Etat de la dette, le travail du deuil et la Nouvelle Internationale, p. 83.

15 Ibid., pp. 212-219.

16 K Marx, Das Kapital, vol. I (1862), (Dietz, Berlin, 1962), p. 76.

17 J Derrida, Spectres de Marx. L'Etat de la dette, le travail du deuil et la Nouvelle Internationale, pp. 254-255.

18 Ibid., p. 173.

19 Ibid., pp. 89, 173, 178, 255. 
still spoken of although this is not meant literally. Also in poetry and in fine art spirits, ghosts and Gods continue to play an important role. Hölderlin expects the appearance or re-appearance of the ancient Gods. According to him Jesus is one of them, although he is 'unique', being the last one and making their appearance complete. ${ }^{20}$ Rilke often invokes God and angels; he wants them to support him in his care for the 'things' and their own right, although he is not sure that they will listen to him. Therefore he asks:

Who, if I would cry, would listen to me from the order of the angels? ${ }^{21}$

In fine art fantastic representations can be found abundantly. I only refer to the bizarre imagination of Salvador Dali, René-FrançoisGhislain Magritte or other surrealistic artists. In the Christian churches, also after Kant's critical theory of cognition, it is spoken of God and angels. In Catholic theology the saints are added to that; they are present in a transcendent sphere and can be invoked for help.

In a conversation with Derrida, when he stayed in Amsterdam in 1994, I asked him, why he had not extended his theory of spirits to those who are present in nature or natural things. In this case he could add to his 'new spectrology' ideas of animism. I referred to African thought and feeling where spirits also dwell in nature. Derrida answered that he acknowledged the necessity to do that. However, he would not do it himself, but asked me to work out such an extension of his theory. In the following section I will try to carry out this task.

\section{Natural things, especially trees, as dwelling places of spirits}

According to African beliefs, spirits can dwell in animals: in lions, for instance, because of their strength, and in snakes because of their wisdom. Also plants, rivers, rocks or certain parts of a landscape can be their dwelling-places. As I have mentioned in the Introduction, trees are especially preferred by them. That is understandable. Trees are the biggest organic things. They can last much longer than an individual human life. It is obvious that the climate and the living conditions on earth are heavily dependent on the existence of trees and of woods.

In his book on Wangari Maathai, whom he calls the 'mother of the trees', Stefan Ehlert describes 'the meaning of trees for the Kikuyus',

20 F Hölderlin, Der Einzige, in: Werke in vier Bänden, ed. M. Schneider, (Walter Hädecke Stuttgart/Weil der Stadt, 1947), Vol. II, pp. 240-245.

21 RM Rilke, Duineser Elegien, in: Ausgewählte Werke, ed. R. Sieber-Rilke/C. Sieber/E. Zinn, (Insel, Leipzig, 1942), Vol. I, p. 253.

TD, 2(2), December 2006, pp. 249-263. 
a people in Central Kenya. The Nobel Peace Prize winner Maathai belongs to these people. To give some basic information about this particular African group and the work of Maathai, I quote from Ehlert's description:

\begin{abstract}
All started with a tree. Ngai, the God, gave Gikuyu, the founding father of the Kikuyus, the land south-west to Mount Kenya. The hart of the land was a wood of fig trees'. Elspeth Huxley, a British journalist, ethnologist and writer, has found out, however, 'that the Kikuyus had a very ambivalent relation to their environment, especially to the wood. They hated the wood, but they also respected it'. By Huxley different reasons are given: 'The wood delivered the fertile land, and the Kikuyus were thankful for that. However, the wood accommodated also the worst enemies of the farmers. There, the birds nested that ate up the seed of the millet. From there, the wood elephants came that devastated the fields. The bushes of the wood were about to overgrow the land. And last but not least in the wood dwelled the bad spirits, which the Kikuyus feared so much. By most of the research is acknowledged 'that Western influences have turned around the originally sustainable way of dealing with the natural resources'. The Kikuyus were shocked that the colonists even did not shrink back from hoeing up the fig trees. As a consequence, their traditional attitude gave way to a reckless mentality of cutting down. ${ }^{22}$
\end{abstract}

Wangari Maathai tries to reconnect her fellow-citizens to the positive aspects of the traditional attitude towards nature and towards trees. In 1977 she founded the Green Belt Movement which was subsequently responsible for planting 30 million trees. In Kenya more than 6000 womens' groups belong to this Movement. They are doing impressive work. But this remains a first step only on the way to re-install in the African mind the respect for nature, which is part of the belief that spirits can dwell in all natural things. And it will be even more difficult and time-consuming to give meaning to the African model on a worldwide scale.

\title{
6. Respect for nature in animism
}

The belief that spirits can dwell in all natural things can also be expressed by saying that all natural things have a soul. Animism as the religion, which is based on this idea, presupposes a certain relation between human beings and the natural world. A feeling of belonging together, of being brother and sister of the natural things, at least an attitude of respect for them are characteristics of this relation. It is the same life-force which is at work in nature and in human existence. This is not meant as a form of romanticism. There are also bad spirits in nature, and it provides not only necessary means for human life, but also dangerous and hostile influences come forth from it.

22 S Ehlert, Wangarai Maathai-Mutterder Bäume. Die erste afrikanische Nobelpreisträgerin, (Herder, Freibdurg/Basl/Wien, 2004), pp. 21-24. 
During the period of colonialism and Christian missionary activity animism was devalued. It was regarded as heathen, primitive, superstitious, belonging to a low level of culture. To become a Christian meant at the same time to climb up on the ladder of social acknowledgement. This religion was estimated as higher, because it belonged to a more powerful culture in terms of weapons and technical means. There was little understanding for a respectful attitude towards natural things.

Indeed, it is the Judeo-Christian influence, that from the very beginning is directed at multiplying humankind and subduing nature, having dominion over it. ${ }^{23}$ Nature becomes an instrument for self-maintenance and self-multiplication of humankind. This was also an important condition for the development of science and technology in the Western world and in the confrontation with animistic cultures of military superiority. Also the mainstream of Western philosophy is characterised by a type of rationality which is used for dominating all things. The own value of nature was pushed into the background. Nietzsche declares the 'will to power' as the main principle of Western thought, Heidegger regards Western history as dominated by the 'essence of technique', and Adorno understands the prevailing form of knowledge as 'knowledge of dominion' (Herrschaftswissen). The philosophers of difference see in this mainstream the forgetting of the Other, everything is reduced to the self of the human being.

Recent environmental philosophy criticises the predominance of technique and the forgetting of nature. This type of philosophy comes to new ethical orientations. It strives after sustainable development and moderate economic growth. ${ }^{24}$ The 'own weight of the things' and 'reverence for nature' are recommended. ${ }^{25}$ Van der Wal argues that humans have to learn again to deal with nature and the natural things carefully and with circumspection. They have to experience themselves 'as a part of the great animated connection of nature'. And he finds sources of inspiration for this new ways of thought inside and outside' the Western tradition. 'For the moment' he decides to stick to the Western sources. ${ }^{26}$

What the 'great animated connection of nature' and the position of

23 Genesis 1, 28-30.

24 H Sachsse, Ökologische Philosophie. Natur - Technik - Gesellschaft, (Wissenschaftliche Buchgesellschaft, Darmstadt, 1984), K van der Wal, "Globalisierung, Nachhaltigkeit und Ethik" in Natur und kultur. Zeitschrift für ökologische Nachhaltigkeit, 4(1), 2003, pp. 100-119.

25 M Coolen and $\mathrm{K}$ van der Wal (eds), Het eigen gewicht van de dingen. Milieufilosofische opstellen, (Damon, Budel, 2002).

26 K van der Wal, "Globalisierung, Nachhaltigkeit und Ethik" in Natur und kultur. Zeitschrift für ökologische Nachhaltigkeit, 4(1), 2003, p. 118.

TD, 2(2), December 2006, pp. 249-263. 
mankind in it means, could be made clear much more directly and precisely by a dialogue with African thought. Mogobe Ramose refers in the first instance to the 'mother earth'. Mother has an enormous impact in African ideas about the family. This becomes evident by a proverb of the Chewa, who live in the present State of Malawi: 'Mother is God number two'. Life is an 'incessant and complex interplay of visible and invisible forces in motion'. Mother and like mother the earth play a highly important role in this. They are the 'preserver of life in the specific forms in which it manifests itself'. Mother earth 'is sacred' and its 'non-injury' must be respected. These demands have not been obeyed in Western science and technique. However, if science and technique use the resources of the earth in a sustainable and moderate way, they would be "neither inconsistent nor incompatible' with these demands. As a 'basis of environmental ethics from an African perspective' can be said: 'Like the mother, the earth has its own dignity ... It deserves reverence and respect'. ${ }^{27}$

The formula 'reverence and respect' expresses what I try to grasp by using the term 'Achtung' in the sense of Immanuel Kant. Achtung is more than respect only. Unlike respect it has an emotional side. Kant calls Achtung, which is related in his context not to nature or to the other, but to the moral law only, a 'reasonable emotion' (vernünftiges Gefüht). This is, according to my interpretation, akin to the eros of Socrates, by which bodily love is transformed into love for wisdom. ${ }^{28}$

Not only the mother earth, but also all that is moving on it, organic and in-organic things, deserve Achtung. Everything is animated, that means, it can be the dwelling-place of a spirit, a deity or the GodHead. Spirits are besides the spirits of the ancestors

the forces of nature; the powers behind storm, rain, rivers, seas, lakes, wells, hills, rocks. They are not just the water or the rock, for they are spiritual powers capable to manifest themselves in many places. ${ }^{29}$

For a number of peoples in West Africa the spirits in nature are nature gods. They give special dignity to the natural things in which they dwell. Parrinder names in this connection 'mountains and forests', 'pools and streams', or 'trees and other local objects'. Again the trees, especially the baobabs, play a conspicuous role. ${ }^{30}$

27 MB Ramose, "The earth 'mother' metaphor: An African perspective" in: F. Elders, Visions of Nature. Studies on the Theory of Gaia and Culture in Ancient and Modern Times, (Free University Press, Brussels, 2004), pp. 203-206.

28 H Kimmerle, "Zum Primat der Achtung als Grundlage des Toleranz-Dialogs" in HR Yousefi and K. Fischer (eds), Interkulturelle Orientierung. Grundlegung des ToleranzDialogs, Teil II: Angewandte Interkulturalität, (Bautz, Nordhausen, 2004), pp. 49-68.

29 G Parrinder, African Traditional Religion, pp. 23-24.

30 Ibid., p. 43. 
That spirits and gods in nature deserve reverence and respect, manifests itself concretely in certain forms of religious veneration, which is often expressed in prayers. It would, however, be inappropriate to say that African people 'worship' animals or other natural things. The Ashanti from Ghana and Ivory Coast, for instance, believe that the earth as the bearer of everything that lives on it, is animated by a 'female principle'. The earth is not a goddess, but it is 'of great importance in life'. Its holy day is Thursday. And it is forbidden, to work on the fields on Thursday.

Before hoeing the land farmers propitiate the earth with offerings of fowls and yams, and at harvest they return thanks to the earth with a libation or a sacrifice. Libations are also made when graves are dug, for it is the earth that receives the dead 'into her pocket'. ${ }^{31}$

I cannot give a detailed description here of the different forms of veneration of the earth, the spirits and the nature gods which are called as a whole animism. It is part of the unfinished process of decolonisation of the mind, that animism is no longer in a subordinate position, but an equal to the 'five world-religions': 'Hinduism, Buddhism, Chinese Universalism, Christianity, Islam', as they are explained by Glasenapp and other philosophers of religion. ${ }^{32}$ In a more recent and also more comprehensive work on World Religions a more adequate place is given to 'African traditional religion'. In the Dutch translation of this work (in 295 pages) it is dealt with in the space of 10 pages. $^{33}$

As far as environmental ethics is concerned, essential insights can be taken over from animism. Workineh Kelbessa from Addis Ababa University discusses in his article 'Indigenous and Modern Environmental Ethics' especially ideas of the Oromo who live in the south of Ethiopia. Central to his discourse is the 'conception of Saffuu'. Saffuu implies, according to the German anthropologist L. Bartels, with whom Kelbessa agrees, "that all things have a place of their own in the cosmic order, and that they should keep this place. Their place is conditioned by the specific Ayyana (soul or spirit) each of them has received from Waaqa (the Supreme Being)'. The concepts of respect and reverence are applied again to describe the attitude of the Oromo towards nature. This does not exclude the fact that 'they have all along been actively manipulating the natural environment'. Their activities have been guided, however, by 'biological and ecological insights' and by 'sustainable resources management systems'. They combine the 'ethic of production' with an 'ethics of preservation', because they know

31 Ibid., p. 48.

32 H Glasenapp, Die fünf Weltreligionen. Hinduismus, Buddhismus, Chinesischer Universismus, Christentum, Islam, (Hugendubel, Kreuzlingen/München, 2001).

33 S McLoughlin (ed), World Religions, (Flame Tree Publishing, London, 2003); Dutch translation: Wereld-religies, (Rebo Productions London, 2005), pp. 108-117.

TD, 2(2), December 2006, pp. 249-263. 
'that without production and transformation of nature human life is unthinkable' and 'that the green environment is a sine qua non for the survival of all living things'. Their contribution to a modern environmental ethics complies with the argument 'that the natural environment has inherent or intrinsic value'. ${ }^{34}$

In her dissertation Narratives for Nature Zwaal analyses a great number of local and supra-local stories in Cameroon. She comes to the conclusion, following for the most part the anthropologist K. Milton, that in these stories differentiated conceptions characterise the attitude of people towards nature. They range from 'fear' with regard to a 'capricious nature' via 'respect' because of a 'strong nature' and 'care' for an 'only within limitations strong nature' to 'compassion' with a 'vulnerable nature', which leads in the end to an attitude of 'protecting nature'. This implies that the forces of nature which act on the human beings and the forces of the human beings which act on nature are and have to be kept in balance. ${ }^{35}$

The research of Kelbessa and Zwaal can show us how the belief in spirits in sub-Saharan Africa can contribute to a modern environmental ethics. African thought and feeling is vicarious here for nonWestern philosophies. Hereby a step is taken from a deconstructive reading of Western philosophy, like Derrida and Van der Wal prefer to carry out, to the inclusion of non-Western philosophies. We aim at installing 'partnership', like Kelbessa formulates, or at an 'intercultural dialogue', in which Zwaal lets us participate.

\section{Final remarks}

As we have seen, African thought and feeling about nature sticks to traditional beliefs and mythical representations. That does not exclude a sober and pragmatic attitude. Respect and reverence for nature, which are founded in the belief that all natural things can be a dwelling-place of spirits, are combined with 'biological and ecological insights' and 'management systems' for sustainable resources, like we have learnt from Kelbessa. I want to conclude by explaining how this double attitude towards nature is expressed in African proverbs on trees, which are preferred dwelling-places of the spirits. In this explanation the meaning of these proverbs, maxims or epigrams is not given in its full dimensions or power, because they are not quoted

34 K Workineh, "Indigenous and Modern Environmental Ethics: Towards Partnership" in GM Presbey a.o. (eds), Thought and Practice in African Philosophy, (Konrad Adenauer Foundation, London, 2002), pp. 47-61, especially 54-57. (Remarks between brackets in the quotation are mine, HK.)

$35 \mathrm{~N}$ Zwaal, Narratives for Nature. Storytelling as a vehicle for improving the intercultural dialogue on environmental conservation in Cameroon, (Diss. Nijmegen 2003), p. 209. 
in their original language, but only in English translation.

The Ashanti in Ghana say: 'A human being is not a palm-tree, he or she is not self-sufficient'. A palm-tree is useful in many ways. Let me name only a few possibilities: The stem is good for building houses or bridges, the leaves are used for packing, from the juice wine can be made. It can be used universally. But a human being is not able to do so many things on his or her own. He or she needs the community for support and for security. The palm-tree seems to be superior to the human being. But the dependence of the humans on their community has its specific value. Gyekye explains this by quoting another proverb or maxim: The well-being of man depends upon his fellow men. ${ }^{36}$

Secondly I refer to a proverb of the Kikuyu in Kenya: 'A tree at the roadside does not lack a scar.' Wanjohi from the University of Nairobi who makes 'the wisdom and philosophy of the Kikuyu' explicit by using their proverbs interprets them on three levels. In a literal sense, one can notice that trees alongside the road mostly have scars. In a metaphorical interpretation 'tree' stands for people in a public position. The 'roadside' means that their position makes them especially vulnerable. And 'scars' cannot be avoided because they are exposed to criticism and envy of others. A third level of interpretation is called by Wanjohi 'polysymbolic'. Like for trees at the roadside it is true for human beings in general that they are vulnerable, that their communication with others always somehow will cause scars. In an even more general sense, I would like to add, according to the maxim of Anaximandros from ancient Greece, all things are guilty with respect to others because there cannot be another thing at the same time in the place where they are. ${ }^{37}$ Thus a signal is given for a tragic, but not for a hopeless situation.

A proverb that is in use in many different African communities says something about wisdom in general, what is, all the more, particularly true for the solution of the problem, which is decisive for the survival of mankind on earth. This problem is can be stated thus: how to find and set into practice an adequate attitude towards nature? Here is the proverb: 'Wisdom is like a baobab, one person alone cannot embrace it.' That means for the named problem: it cannot be solved by the philosophy of one culture alone, intercultural philosophical dialogues are necessary for that.

36 K Gyekye, "Person and Community in African Thought" in H Kimmerle (ed), $I$, We and Body, p. 54.

37 GJ Wanjohi, The Wisdom and Philosophy of the Gikuyu Proverbs: The Kihooto Worldview, (Paulines Publications Africa, Nairobi, 1997), pp. 71-72; cf. for the maxim of Anaximandros: Wilhelm Capelle (ed), Die Vorsokratiker: Fragmente und Quellenberichte, (Kröner, Stuttgart 1973), p. 82.

TD, 2(2), December 2006, pp. 249-263. 